\title{
PEMBENTUKAN KARAKTER ANAK GEMAR MEMBACA MELALUI PEMBACAAN BUKU CERITA
}

\author{
Encang Saepudin $^{1 *}$, Ninis Agustini Damayani ${ }^{2}$, Neneng Komariah ${ }^{3}$ \\ ${ }_{1,2,3}$ Prodi Ilmu Perpustakaan, Universitas Padjadjaran \\ Korespondensi: encang@unpad.ac.id
}

Submission: 17-01-2020; Review: 05-03-2020; Accepted: 26-08-2020; Revised: 08-11-2020

\begin{abstract}
This study aims to determine the process of building children's character who likes reading through reading story books. The research objectives are knowing the storytelling process and the benefits of storytelling in building the character of children who love reading. Qualitative research methods with a case study approach. The source of research data is one community leader, two managers of the Taman bacaan Permata Hati, and one person from the education office. Collecting data through interviews with key informants, direct observation of research objects, and literature studies. Test the validity of the data through triangulation. Descriptive data analysis through stages of reduction, presentation, and drawing conclusions. The results showed that the storytelling process to build the character of children who love reading is to set goals, form of storytelling, supporting facilities, storytelling steps, and assessment design.
\end{abstract}

\begin{abstract}
ABSTRAK
Penelitian bertujuan untuk mengetahui proses membangun karakter anak gemar membaca melalui pembacan buku cerita. Penelitin ini bertujuan untuk mengetahui proses bercerita dan manfaat bercerita dalam membangun karakter anak gemar membaca. Metode penelitian kualitatif dengan pendekatan studi kasus. Sumber data penelitian satu orang tokoh masyarakat, dua orang pengelola Taman bacaan Permata Hati, dan satu orang dari dinas pendidikan. Pengumpulan data melalui proses wawancara dengan informan kunci, observasi langsung pada objek penelitian, dan studi literatur. Uji keabsahan data melalui triangulasi. Analisis data secara deskriptif melalui tahapan reduksi, penyajian, dan penarikan kesimpulan. Hasil penelitian menunjukkan bahwa proses bercerita untuk membangun karakter anak gemar membaca adalah menetapkan tujuan, bentuk bercerita, sarana pendukung, langkah-langkah bercerita, dan rancangan penilaian.
\end{abstract}

Keywords: Storytelling; Reading habits; Characters; Critical thinking; Knowledge; Children

\section{PENDAHULUAN}

Bercerita adalah tradisi lisan yang sudah hidup sebelun manusia mengenal tulisan. Dalam perkembangan kemampuan berbahasa, bahasa lisan merupakan kemampuan awal yang dimiliki setiap orang sebelum mampu mengenal huruf dan membanca. Anak-anak sebelum dapat mengenal huruf dan mampu membaca terlebih dahulu dapat berbicara dan mendengar. Pengembangan sistem bahasa lisan menjadi landasan dalam mempersiapkan anak belajar membaca. Kemampuan anak dalam berbicara mengambarkan penguasaan terhadap kosa kata bahkan struktur bahasa. Hal ini menggambarkan bahwa semakin anak banyak berbicara berarti anak tersebut banyak menguasi kosa kata.

Dalam dunia pendidikan, membaca merupakan aktivitas pokok. Baik siswa maupun tenaga pendidik menempatankan aktivitas membaca pada psisi penting. Khusus bagi para siswa, membaca selain menjadi kewajiban dalam belajar namun harus menjadi wahana hiburan. Melalui membaca, para siswa memperoleh kesenangan sekaligus pengetahuan sebagai pengembang wawasannya. Para siswa mendapatkan pengetahuan baru, informasi, sekaligus hiburan. Rachmayani (2014) mengemukakan bahwa membaca merupakan proses berfikir yang mengandalkan gerakan mata dan cara kerja otak. Melalui membaca akan melatih diri anak-anak baik seacara fisik maupun mental. Pada saat membaca anak-anak sedang melatih daya pikir dan daya fisik. Selain melatih memahami isi bacaan, pada saat membaca anak-anak melatih kemampuan mata, telinga, dan lisan. Hal ini sejalan dengan pernyataan Susanti (2002) yang mengutip Kamus Besar Bahasa Indonesia 
dijelaskan bahwa membaca adalah melihat serta memahami isi dari apa yang tertulis dengan melisankan atau hanya dalam hati.

Sesungguhnya apa yang menjadi tantangan kita dewasa ini adalah meningkatkan minat dan budaya baca masyarakat. Tantangan ini dapat dilihat dari data Badan Statistik Indonesia tahun 2008 yang menggambarkan angka buta huruf mencapai 8,7\%, baru di tahun 2010 angka melek huruf menjadi 92\%. Data tersebut menggambarkan bahwa masyarakat Indonesia masih ada yang belum mampu membaca. Banyak langkah yang dapat dilakukan untuk membangun gemar membaca pada anak-anak, yakni melalui mendongeng, bercerita, atau berkisah. Ketiganya melibatkan aktivitas lisan. Penggunaan bahasa lisan merupakan langkah awal dalam fase belajar berbahasa. Fase belajar bahasa individu dimulai dari kegiatan menyimak, mendengarkan, menyimpan di memori, berbicara, dan menulis (Gasong, 2018).

Langkah awal pengenalan keterbacaan pada anak dapat melalui bercerita atau mendongeng. Melalui kegiatan mendongeng, anak akan terbiasa menyerap pengetahuan dan pengalaman berbeda. Dongeng dapat menjadi media yang tepat untuk membangun karakter dan penanaman nilai moral dan etika pada diri anak. Menurut Pellowski (1997) dan Qisty (2011) mendongeng merupakan seni dari sebuah keterampilan bernarasi dalam bentuk syair dan prosa, yang dipertunjukkan dengan cara dinyanyikan, diceritakan, dengan atau tanpa musik, menggunakan alat peraga atau tanpa alat peraga, diperoleh dari sumber tercetak atau rekaman mekanik.

Kegiatan mendongeng sangat dekat dengan dunia anak. Seperti kita ketahui bahwa dunia anak merupakan dunia bermain. Belajar sambil bermain merupakan metode pembelajaran yang cocok untuk anak-anak. Bunanta (2009) mengatakan bahwa ada berbagai konsep mendongeng yang dapat digunakan untuk mengajak anak membaca. Konsep mendongeng dan bermain, mendongeng sambil bermain musik, mengadakan festival mendongeng dengan konsep pementasan teater dari anak untuk anak, dan lain sebagainya.

Salah satu penelitian mengenai peran dongeng dalam membentuk karakter anak telah dilakukan oleh Soetantyo (2013), yang mengatakan bahwa dunia internet sudah menjadi gaya hidup para siswa. Untuk mengimbangi arus informasi yang diterima oleh anak-anak melalui media internet, yakni melalui proses pendidikan karakter. Proses pengembangan diri anak melalui pendidikan karakter ini harus terintegrasi dalam berbagai aktivitas kehidupan. Aktivitas kehidupan anak harus mendapat perhatian secara khusus baik di rumah maupun di sekolah. Pembangunan karakter anak dapat dilaksanakan melalui kegitan sosialisai, internalisasi, pembiasaan, dan pembudayaan. Keempat kegiatan ini harus sistematis dan selaras antara pendidikan di rumah dan di sekolah. Salah satu aktivitas yang dapat dilakukan baik di rumah maupun di sekolah adalah pembacaan buku cerita. Melalui aktivitas bercerita anak dapat memahami karakter dari setiap tokoh yang ada dalah buku, bahkan anak dapat secara mandiri mengenal tokoh baik dan tokoh jahat dari sebuah cerita. Secara tidak langsung anak-anak dapat membedakan mana tokoh yang memiliki sifat baik dan mana tokoh yang mimiliki sifat buruk.

Mendongeng sebagai sebuah strategi pembelajaran dalam membangun karakter anak sudah terbuktikan dari beberapa hasil penelitian mengenai penerapan mendongeng sebagai metode pembelajaran. Penelitian yang dilakukan oleh Kusmiadi (2008) membuktikan bahwa melalui metode mendongeng dapat membangun karakter anak secara positif dan menumbuhkembangkan seluruh potensi kecerdasan anak secara optimal. Penelitian berikutnya dilakukan oleh Pebriana (2017), membuktikan bahwa memdongeng merupakan cara yang tepat untuk menanamkan moral dan nilai-nilai kehidupan pada diri anak. Hal ini terjadi karena pada saat anak-anak menyimak cerita terjadi proses tranformasi nilai melalui perilaku dan karakter tokoh dalam cerita. Melalui kegiatan mendongeng anak-anak dapat menyimak isi pesan/informasi terutama karakter tokoh dalam cerita. Pesan-pesan yang ada dalam cerita dapat mempengaruhi kemampuan emosi, imajinasi, dan perilaku anak. 
Berdasarkan kepada beberapa hasil penelitian tersebut, dapat disimpulkan bahwa bercerita melalui media buku dapat menjadi stimulan yang baik bagi anak dalam menguasai kosa kata. Membangun jiwa anak supaya gemar membaca merupakan hal utama bila dibandingkan dengan proses mengajarkan membaca. Menstimulasi untuk gemar membaca akan memberi pengaruh yang menyenangkan, sedangkan mengajarkan membaca membuat anak terbelenggu dengan aturan dan perintah sehingga merasa terpaksa. Melalui proses bercerita anak akan dikenalkan dengan berbagai kosa kata baru, secara tidak langsung mereka sudah belajar dan menambah kosa katanya. Penelitian ini bertujuan untuk menjelaskan proses dalam membangun karakter anak agar gemar membaca melalui pembacan buku cerita, baik melalui proses bercerita maupun memahami manfaat ketika bercerita.

\section{TINJAUAN PUSTAKA}

Pembentukan karakter sejak dini merupakan upaya membangun masyarakat yang cerdas dari segi intelektual ataupun moral. Masa awal kehidupan merupakan masa-masa yang menentukan terhadap pembentukan kepribadian (Hildayani, 2014). Pelaksanaan pendidikan karakter sejak dini merupakan proses internalisasi nilai-nilai moral, sosial, dan agama dalam diri anak. Melalui proses ini akan mewarnai perilaku dan kepribadian anak sehinggan terbangun perilaku positif (Rijal, 2011).

Lidyasari (2013) mengatakan bahwa pembentukan karakter anak dimulai dari lingkungan keluarga. Keluarga merupakan lingkungan pertama dalam membangun karakter anak. Anak-anak mempelajari karakter melalui model perilaku para anggota keluarga. Model perilaku baik akan berdampak positif terhadap perkembangan karakter anak begitu pun sebaliknya. Hal ini sangat bergantung pada pola asuh atau interaksi antaranggota keluarga. Pola asuh orang tua dapat dibagi menjadi tiga jenis yakni otoriter, permisif, dan otoritatif. Dari setiap pola asuh tersebut sangat berpengaruh terhadap perilaku dan kepribadian anak. Dari ketiga pola asuh tersebut model otoritatif merupakan pola yang paling cocok untuk membentuk karakter anak. Hal ini disebabkan oleh sifatsifat dari pola asuh yaitu demokratis, menghargai dan memahami keadaan anak sesuai dengan kelebihan dan kekuangannya. Dengan menerapkan pala asuh otoritatif di dalam keluarga anak akan tumbuh menjadi pribadi yang matang, sederhana, dan dapat menyesuaikan diri dengan lingkungannya secara baik.

Eliasa (2011) menjelaskan bahwa seorang anak akan mengalami kecemasan, kemarahan, bahkan penyimpangan perilaku apabila kurang memperoleh perhatian dan kasih sayang dari ibu. Oleh karena itu, perlu dibangun kedekatan dan kelekatan antara orang tua terutama ibu dengan anaknya. Kelekatan seorang ibu dan anak melalui internal working model dapat membangun karakter anak sehingga anak akan memiliki perilaku sosial yang baik, emosi yang seimbang, dan jiwa yang kuat. Ibu sebagai pengasuh utama anak memegang peranan penting dalam penentuan status kelekatan anak, apakah anak akan membentuk kelekatan aman atau sebaliknya. Status kelekatan ini berhubungan dengan gangguan kelekatan dan perkembangan anak di masa selanjutnya. Hal ini menggambarkan bahwa hubungan orang tua dan anak menjadi sumber emosional dan pengalaman kognitif untuk diri anak. Kualitas hubungan anak dan orang tua akan membangun kontruksi mental anak mengenai dirinya dan orang lain. Selain itu, hubungan tersebut merupakan kesempatan anak dalam mengeksplorasi lingkungan dan kehidupan sosial.

\section{METODE}

Penelitian ini menggunakan metode kualitatif dengan pendekatan studi kasus. Pertimbangan pemilihan metode ini yaitu objek penelitian berupa peristiwa dari tingkah laku manusis. Peristiwa ini diamati secara intensif, terinci, dan mendalam (Raco, 2018). Pengumpulan data melalui proses wawancara dengan informan kunci, observasi langsung pada objek penelitian, dan studi literature 
terkait dengan objek penelitian. Narasumber kunci terdiri atas empat orang yaitu satu orang tokoh masyarakat, dua orang dari pengelola Taman Bacaan Permata Hati, dan satu orang dari dinas pendidikan. Pertimbangan pemilihan narasumber adalah keterlibatan dan pemahaman para narasumber terhadap pokok penelitian, yakni pembentukan karakter anak gemar membaca.

Langkah pertama adalah mengobservasi kegitan pembacaan buku cerita di Taman Bacaan Permata Hati, untuk memperoleh data primer secara objetif. Melalui observasi langsung, peneliti mendapatkan data penelitian secara alamiah terutama mengenai proses bercerita. Kemudian, wawancara langsung dengan informan kunci yaitu para pengelola taman bacaan, yang bertujuan untuk menguatkan data hasil observasi atau mengecek ulang data hasil observasi. Data yang terkumpul kemudian diolah dan dianalis. Pengolahan dimulai dari penilaian, klasifikasi, deskripsi, abstraksi, dan penarikan simpulan. Proses penilaian data dilakukan untuk menentukan data yang paling bernilai untuk mendukung proses analisis. Klasifikasi dilakukan untuk mengelompokkan data berdasarkan tujuan penelitian. Deskripsi data dilakukan dengan menafsirkan dan memaknai data sesuai dengan nilai konsep yang digunakan. Penarikan kesimpulan berdasarkan data hasil analisis.

\section{HASIL DAN PEMBAHASAN}

Mendongeng menggunakan buku dapat membangun jiwa anak untuk menjalani proses membacanya. Mendongeng menjadi salah satu tahapan dalam proses membangun kemampuan dan kebiasaan membaca anak. Pada proses ini anak dikenalkan dengan media baca, yakni buku disamping mereka mengenal kosa kata dan struktur bahasa. Melalui mendongeng anak-anak belajar kata, merangkai kata, bahkan menyusun kalimat hasil mendengarkan selama proses mendongeng. "Proses belajar kosa kota ini walaupun masih dalam konteks bahasa lisan namun dapat menjadi bekal dalam proses belajar membaca" (Rumdiani, wawancara, Juli 2019).

Selain anak-anak belajar kosa kata dalam mendongeng, mereka harus bersedia bersentuhan dengan buku, kemudian membuka dan membacanya hingga mereka menjadi penasaran dengan isi buku. Kondisi ini menggambarkan anak-anak sudah mulai tertarik terhadap buku sehingga akan meningkatkan minat bacanya. Menceritakan kisah tertentu kepada anak dengan membacakan buku akan menjadi contoh langsung bagi anak-anak mengenai membaca. Sebagaimana yang dikatakan pengelola Taman Bacaan Permata Hati, bahwa "apabila anak-anak sudah dikenalkan dengan buku sebagai sumber bacaan sejak kini, maka ketika sudah besar akan memiliki minat yang tinggi terhadap buku" (wawancara, Juli 2019).

Minat baca diartikan sebagai kecenderungan hati yang tinggi seseorang terhadap suatu bahan bacaan (Sutarno, 2006). Kegiatan membaca cerita terhadap anak perlu dilakukan secara teratur dan berkelanjutan agar dapat menumbuhkan minat membaca mereka. Sebagaimana yang dikatakan oleh pihak dari dinas pendidikan, bahwa "anak-anak harus dibiasakan dan dikenalkan dengan buku sebagai media membaca; dengan melihat orang membacakan buku cerita yang menarik, anak akan tertarik untuk mendengarkan dan mencontoh; dan secara tidak langsung, pembaca buku cerita telah memberikan contoh kepada anak tentang bagaimana cara membaca buku" (wawancara, 4 Juli 2019).

Pernyataan tersebut menggambarkan bahwa kegemaran membaca dipengaruhi oleh kondisi emosional atau kondisi-kondisi tertentu pada diri anak di masa usia dini. Ketika seorang anak memperoleh pengalaman yang menyenangkan pada saat dibacakan sebuah buku, di dalam pikiran dan perasaan anak akan tertanam bahwa kegiatan membaca merupakan pengalaman yang menyenangkan, dan mendongeng pada anak usia dini dapat menjadi dasar yang kuat untuk membangun kebiasaan membaca anak. Cerita yang dibawakan kepada anak-anak dapat berupa kisah tradisional atau kisah tentang legenda, mitos, atau cerita binatang (Sulistyo-Basuki, 2011). 
Aktivitas mendongeng akan meningkatkan hubungan yang kuat antara pencerita dan pendengar, dalam konteks ini antara pengelola taman bacaan dan anak-anak.

Kegiatan mendongeng di taman bacaan masyarakat bertujuan untuk menarik minat anak-anak agar datang dan memanfaatkan berbagai fasilitas layanan yang disediakan (Saepudin, 2017). Dalam proses bercerita harus memiliki daya tarik dan memikat anak-anak. Ada beberapa cara untuk memikat anak-anak agar dapat mengikuti kegiatan mendongeng yaitu cerita yang disampaikan harus sesuai dan dekat dengan kehidupan mereka, cara penyampaian cerita dengan gaya dan teknik yang menarik untuk anak-anak, misalnya dengan menggunakan alat bantu cerita (gambar, boneka) dan disertai humor, serta melibatkan anak-anak dalam proses cerita. Hal tersebut dilakukan untuk meningkatkan kebiasaan anak dalam membaca dan bercerita. Hal terpenting dari membaca ada membangun motivasi anak untuk membaca sejak dini, dan menunjukkan bahwa membaca adalah kegiatan yang menyenangkan (Saputro, 2012).

\subsection{Bercerita Sebagai Metode Pembelajaran}

Strategi pembelajaran melalui bercerita merupakan usaha pencerita dalam mencapai tujuan pendidikan yang telah ditetapkan. Menurut Masitoh (2006), strategi pembelajaran adalah pola umum perbuatan pencerita dan murid dalam perwujudan kegiatan belajar mengajar. Kegiatan pencerita dalam mengajar dan kegiatan siswa pada saat belajar, dan bercerita merupakan seni untuk menyampaikan suatu peristiwa melalui pernyataan lisan, imajinasi, dan bunyi (Ismoerdijahwati, 2007). Aktivitas bercerita sebagai kegiatan belajar harus memperhatikan beberapa hal yakni cerita harus dekat dengan kehidupan anak, cerita disampaikan pada suasana menyenangkan, dan cerita harus mengandung pesan baru bagi anak-anak.

Kegiatan bercerita sebagai sarana belajar harus dapat mendukung ketercapaian tujuan pendidikan baik kognitif, afektif, maupun motorik. Sebagaimana yang dikatakan pihak dinas pendidikan bahwa "apabila bercerita dikaitan dengan proses pembelajaran maka bercerita menjadi salah satu motode pembelajaran, bercerita harus dapat mendorong dalam mencapai tujuan pembelajaran, pencerita memiliki kebebasan dalam meilih tema cerita, sebaiknya cerita yang dipilih harus dekat dengan kehidupan anak dan mampu mendorong ketercapaian tujuan pembelajaran". Masitoh (2006) menjelaskan ada lima langkah bercerita, yaitu menentukan tujuan, bentuk bercerita, bahan dan alat, rancangan bercerita, dan penilaian bercerita.

1) Menentukan tujuan. Tujuan bercerita yang dilaksanakan di Taman Bacaan Permata Hati adalah mengenalkan buku dan membiasaan anak-anak untuk membaca buku. Hal ini dikemukakan oleh pengelola Taman Bacaan Permata Hati bahwa dengan pembacaan buku cerita, anak-anak dikenalkan dengan media baca. Diharapkan semakin mengenal media baca buku, mereka menjadi cinta buku dan gemar membaca" (Rumdiani, wawancara, Juli 2019).

2) Menetapkan bentuk bercerita, diselaraskan dengan kondisi pengalaman hidup anak agar dapat menjiwai seluruh isi cerita. Penjiwaan isi cerita akan membantu dalam memahami isi cerita. Melalui penjiwaan yang baik, pesan yang terkadung dalam cerita mudah untuk dihayati dan tertanam dalam pikiran anak. Pembacaan buku cerita yang dilakukan di Taman Bacaan Permata Hati merupakan bentuk layanan melalui pembacaan buku cerita anak-anak yang mengandung pesan moral. Ketika pencerita membacakan buku secara tidak langsung sudah memberi contoh tentang bagaimana membaca, memahami, dan menghayati sebuah cerita melalui media buku. Anak-anak tidak hanya dicontohkan karakter para tokoh dalam cerita, tetapi juga karakter langsung dari diri pencerita.

3) Sarana yang digunakan, untuk mendukung aktivitas pembacaan buku cerita disesuaikan dengan bentuk cerita yang telah ditetapkan. Dalam pembacaan buku cerita, selain buku cerita juga ada beberapa sarana pendukung aktivitas bercerita. Sebagai contoh, pada saat tema yang diceritakan tentang binatang, maka boneka binatang digunakan untuk sarana pendukungnya. 
Boneka menjadi sarana untuk memvisualisasikan karakter para tokoh dalam cerita, dan memperkuat karakter dari para tokoh dalam cerita. Berdasarkan hasil wawancara dengan pengelola Taman Bacaan Permata Hati, "bercerita dimulai dari menyampaikan tujuan, menata tempat duduk untuk anak-anak, menyampaikan cerita, dan mengevaluasi kegiatan bercerita, anak-anak menjadi lebih fokus dan terarah, serta dapat mengungkapkannya secara verbal dan nonverbal.

4) Penataan tempat duduk disesuaikan dengan jumlah anak. Membacakan buku cerita dilaksanakan dalam kelompok kecil antara 13-15 anak. Hal ini dilakukan dengan pertimbangan bahwa anak-anak memiliki keterbatasan dalam mempertahankan perhatian. Anak-anak mudah pudar perhatiannya. Pencerita harus memperhatikan secara penuh seluruh peserta. Melalui pola melingkar dan jumlah peserta cukup kecil, pencerita memiliki keleluasaan dalam memberikan perhatian pada anak secara keseluruhan. Pencerita harus memahami pengalaman anak-anak ada hal-hal yang disukai oleh mereka. Pencerita harus memiliki imajinasi dan mengilustrasikan isi bacaan melalui bahasa dan gerak. Tahap ahkhir kegiatan membacakan buku cerita adalah tanggapan dari anak-anak yang mengikuti kegiatan bercerita. Tanggapan anak-anak menjadi indikator ketercapaian tujuan kegiatan. Apabila diakhir kegiatan mereka mampu menggambarkan isi cerita secara singkat dengan bahasa sendiri melalui ekspresi yang menarik, berarti kegiatan bercerita dengan buku dikatakan berhasil.

5) Penilaian merupakan uraian kegiatan dalam menafsirkan proses dan hasil belajar peserta didik yang dilaksanakan secara sistematis dan berkesinambungan untuk mengukur keberhasilan kegiatan belajar. Hasil penilaian menjadi dasar pengambilan keputusan. Penilaian aktivitas bercerita di Taman Bacaan Permata Hati masih sangat sederhana, yaitu melalui penilaian langsung dari para peserta. Pada saat akhir kegiatan, mereka diberi kesempatan untuk menyampaikan pendapatnya terkait tema yang dipilih, buku yang dibaca, cara penyampaian cerita, suasana, dan sarana yang digunakan. Pendapat para peserta menjadi acuan untuk mengevaluasi kegiatan, dan bahan perbaikan proses berikutnya.

\subsection{Manfaat Membacakan Cerita dalam Membetuk Karakter Anak}

Kegiatan mendongeng di taman bacaan masyarakat dapat berfungsi sebagai pelestari budaya dan memberi inspirasi untuk masa depan. Kegiatan mendongeng cerita masa lalu dapat tetap terjaga dan bagi anak-anak yang mendengarkan cerita menjadi terinspirasi untuk kehidupannya di masa yang akan datang (Saepudin, 2017). Bercerita dan mendengarkan cerita dapat melepaskan rasa emosional melalui pengalaman fiktif yang tidak pernah disampaikan anak-anak secara alami. Kegiatan mendongeng juga dapat mengembangkan aspek pengetahuan, perasaan, sosial, dan penghayatan diri anak. Mendongeng merupakan kegiatan yang sangat efektif untuk membina dan mengembangkan kepribadian anak (MacDonald, 1995; Asfandiyar, 2007; \& Musfiroh, 2008).

Berdasarkan hasil wawancara dengan pengelola Taman bacaan Permata Hati dan tokoh masyarakat, ada beberapa manfaat dari kegiatan mendongeng di taman bacaan masyarakat, yakni sebagai berikut.

1) Penanaman nilai-nilai kehidupan

Melalui proses mendongeng anak-anak belajar mengenai nilai-nilai kehidupan manusia tanpa diajari. Melalui cerita yang disampaikan, anak-anak dapat belajar dari karakter tokoh dalam cerita. Karakter para tokoh ini membuat anak-anak lebih mengenal persahabatan, persaudaraan, menghormati orang tua, mencintai alam, dsb. Cerita rakyat mendeskripsikan karakter tokoh secara hitam-putih (baik dan jahat). Melalui pengenalan karakter ini anak-anak dapat mengenal nilai-nilai kehidupan tanpa dipaksa untuk belajar, seperti nilai edukatif, nilai sosial, nilai moral, 
nilai agama, atau nilai-nilai humanisme sehingga bermanfaat bagi pembaca. Nilai moral berkaitan dengan akhlak atau budi pekerti dan tingkah laku manusia. Nilai berkaitan dengan norma yang berada dalam kehidupan masyarakat. Nilai keagamaan berkaitan dengan tuntunan beragama. Nilai pendidikan berkaitan dengan pengubahan tingkah laku dari buruk menuju baik.

2) Membangun kemampuan berbahasa

Mendengarkan cerita pada dasarnya sedang berlatih berbahasa. Bercerita kepada anak-anak tidak hanya menghibur, tetapi namun sedang melatih kamampuan berbahasa mereka. Seorang pencerita harus mampu memilih buku cerita yang syarat dengan kata-kata baru, istilah baru, atau ungkapan baru. Pada saat mendengarkan cerita, anak-anak sedang belajar dan meningkatkan kemampuan berbahasanya, serta menyerap berbagai kosa kata, istilah, ungkapan, dan kalimat. Kosa kata baru atau istilah baru yang mereka serap selama mendengarkan cerita menjadi perluasan kosa kata/pembendaharaan kata mereka. Semakin banyak kosa kata yang mereka miliki maka keterampilan berbahasa mereka semakin tinggi. Karena keterampilan berbicara anak-anak harus didukung oleh pembendaharaan kata yang cukup sesuai dengan perkembangannya.

3) Memicu daya berpikir kritis anak

Beriikir kritis adalah kegiatan menganalisis ide atau gagasan ke arah yang lebih spesifik, membedakannya secara tajam, memilih, mengidentifikasi, mengkaji dan mengembangkannya ke arah yang lebih sempurna (Wijaya, 2010). Kemampuan berpikir kritis dapat mendorong seseorang melahirkan ide baru mengenai permasalahan yang dihadapi. Melalui cerita anakanak dilatih untuk menyeleksi berbagai karakter yang digambarkan oleh setiap tokoh, sehingga dapat membedakan karakter baik dan buruk, benar atau salah. Anak-anak dapat memberi kesimpulan berdasarkan alur cerita yang disampaikan siapa tokoh baik dan siapa tokoh jahat, bagaimana karakter tokoh baik dan bagaimana karakter tokoh jahat.

4) Merangsang daya imajinasi dan fantasi anak

Sebuah cerita yang disajikan dalam konteks olah pikir dapat membangun kemapuan imajinasi pada diri anak. Berimajinasi bagi anak usia dini sangat penting untuk pengembangan kognitif, sosial-emosi, bahasa, seni, dan moral. Dengan berimajinasi, anak-anak dapat mengungkapkan mengenai keadaan lingkungan, peristiwa yang terjadi disekitar, dan benda-benda yang ada di sekitarnya. Imajinasi adalah kemampuan berpikir divergen seseorang yang dilakukan tanpa batas, seluas-luasnya dan multi perspektif dalam merespon suatu stimulasi" (Rachmawati \& Kurniaty 2010). Selain itu, anak-anak juga dapat mengembangkan daya pikir dan daya cipta tanpa batas. Mereka ingin mengetahui lingkungan sekitar, keberadaan diri, peran dirinya dalam lingkungan, serta menjadi bagian dari lingkungannya. Sebagaimana dikatakan Yulianti (2010) bahwa pada masa usia dini terjadi pematangan fungsi-fungsi fisik dan psikis yang siap merespons stimulasi yang diberikan oleh lingkungan.

5) Melatih daya konsentrasi

Daya konsentrasi merupakan kemampuan untuk memusatkan perhatian, pikiran, dan fisik pada sebuah objek. Salah satu faktor kesulitan anak berkonsentrasi pada saat belajar adalah ketidaktertarikan mereka terhadap materi dan metode pembelajaran. Pada umumnya, kemampuan konsentrasi anak tidak akan jauh dari usia mereka. Contohnya, anak usia 8 tahun memiliki daya konsentrasi rata-rata 8 menit untuk mendengarkan cerita atau dongeng. Dalam 
mendongeng, anak-anak diminta tidak hanya mendengarkan tetapi juga diminta berkonsentrasi dengan materi cerita yang disampaikan oleh pencerita.

6) Mendorong anak mencintai buku dan merangsang minat baca anak

Ketika pencerita membacakan buku, sebenarnya ia sedang mengajari anak-anak untuk membaca buku. Ketika anak-anak merasa tertarik dengan cerita yang disampaikan, maka pikirannya akan mudah mengingatnya, dan jika ingin membaca sebuah cerita maka yang dicari adalah buku.

\section{KESIMPULAN}

Ada beberapa langkah dalam bercerita untuk membentuk karakter anak gemar membaca yaitu menentukan tujuan dan tema cerita, cara bercerita, sarana pendukung bercerita, tahapan bercerita, dan rancangan penilaian bercerita. Manfaat membacakan cerita bagi anak diantaranya dapat membentuk karakter anak, terutama penanaman nilai-nilai kehidupan, membangun kemampuan berbahasa, memicu daya berpikir kritis, merangsang daya imajinasi dan fantasi, mampu melatih daya konsentrasi, membuka cakrawala pengetahuan, dan mendorong minat baca anak. Dengan demikian, kegiatan membacakan buku cerita dapat membetuk karakter dan pembiasaan membaca anak.

\section{DAFTAR PUSTAKA}

Basuki, S. 2011. Pengantar Ilmu Perpustakaan. Jakarta: Universitas Terbuka.

Bunanta, M. 2009. Buku, Dongeng, dan Minat Baca, Jakarta: Murti Bunanta Foundation.

Departemen-Pendidikan-Nasional 2018. Rancangan Penilaian Hasil Belajar. Jakarta.

Eliasa, E.I. 2011. Pentingnya Kelekatan Orang Tua dalam Internal Working Model untuk Pembentukan Karakter Anak (Kajian Berdasarkan Teori Kelekatan dari John Bowlby). Yogyakarta: Universitas Negeri Yogyakarta.

Gasong, D. 2018. Belajar dan Pembelajaran. Deepublish.

Hildayani, R., Sugianto, M., Tarigan, R., \& Handayani, E. 2014. Psikologi Perkembangan Anak.

Indonesia, P.R. 2007. Undang-Undang Republik Indonesia Nomor 17 Tahun 2007 Tentang Rencana Pembangunan Jangka Panjang Nasional Tahun 2005-2025. Jakarta.

Ismoerdijahwati, K. 2007. Metode Bercerita.

Kusmiadi, A., Sriwahyuningsih, S., \& Nurfalah, Y. 2008. Strategi Pembelajaran PAUD melalui Metode Dongeng bagi Pendidik PAUD. Jurnal Ilmiah Visi, 3(2), 198-203.

Lidyasari, A.T. 2013. Pola Asuh Otoritatif sebagai Sarana Pembentukan Karakter Anak Dalam Setting Keluarga. di http://staff. new. uny. ac. id> upload> penelitian.

Masitoh. 2006. Strategi Pembelajaran TK. Jakarta: Universitas Terbuka.

Miles, B.M. \& Michael, H. 1992. Analisis Data Kualitatif Buku Sumber tentang Metode-Metode Baru. Jakarta: UIP.

Musfiroh, T. 2008. Memilih, Menyusun, dan Menyajikan Cerita untuk Anak Usia Dini. Yogyakarta: Tiara Wacana. 
Pebriana, P.H. 2017. Analisis Kemampuan Berbahasa dan Penanaman Moral pada Anak Usia Dini melalui Metode Mendongeng. Jurnal Obsesi: Jurnal Pendidikan Anak Usia Dini, 1(2), 139-147.

Qisty, S.N. 2011. Pengaruh Mendongeng dalam Memotivasi Kegiatan Membaca Anak di Kebukit. Skripsi. Bandung: Universitas Padjajaran.

Rachmayani, D. 2014. Penerapan Pembelajaran Reciprocal Teaching untuk Meningkatkan Kemampuan Komunikasi Matematis dan Kemandirian Belajar Matematika Siswa. JUDIKA (Jurnal Pendidikan Unsika), 2(1).

Raco, J. 2018. Metode Penelitian Kualitatif: Jenis, Karakteristik, dan Keunggulannya.

Rijal, A. 2011. Kurikulum Pembelajaran Fiqih Madrasah Tsanawiyah Perspektif Pendidikan Holistik Berbasis Karakter: Upaya Pembangunan Karakter Bangsa. Disertasi. Surabaya: UIN Sunan Ampel.

Saepudin, E., Sukaesih, S., \& Rusmana, A. 2017. Peran Taman Bacaan Masyarakat (TBM) bagi AnakAnak Usia Dini. Jurnal Kajian Informasi \& Perpustakaan, 5(1), 1-12.

Saputro, B.E. 2012. Peningkatan kemampuan Membaca Permulaan Anak Usia Dini melalui Metode Cerita Gambar Seri pada Anak Didik Kelompok B di TK Bhayangkari Tahun Pelajaran 2011/2012. Disertasi. Surakarta: Universitas Muhammadiyah Surakarta.

Soetantyo, S.P. 2013. Peranan Dongeng dalam Pembentukan Karakter Siswa Sekolah Dasar. Jurnal Pendidikan, 14(1), 44-51.

Susanti, R. 2002. Penguasaan Kosakata dan Kemampuan Membaca Bahasa Inggris. Jurnal Pendidikan Penabur, 1(1), 87-93.

Sutarno, N.S. 2006. Mengenal Perpustakaan. Jakarta.

Wijaya, C. 2010. Pendidikan Remedial. Bandung: Remaja Rosdakarya.

Yulianti, D. 2010. Belajar Sains di Taman Kanak-Kanak. Jakarta: Indeks. 